\title{
Higher Education Institutions and Post-Covid In-Demand Employability Skills: Responding Through Curriculum that Works
}

\author{
Samuel O. Babalola ${ }^{1 *}$, and Clement O. O. Kolawole ${ }^{2}$ \\ ${ }^{1,2}$ University of Ibadan, Nigeria \\ *e-mail: so.babalola@mail.ui.edu.ng
}

\begin{abstract}
This study explained that the post-Covid world of work would demand a new set of employability skills. Higher education institutions need to respond by preparing graduates with manifest post-COVID-19 employability skills through innovatively delivered curricula. Through literature review, the study identified post-Covid-19 in-demands employability skills and ways of innovatively fostering them. The study adopted the descriptive survey method and canvassed (104) faculty members' (from 9 public universities) opinions through an online poll on the skills they considered relevant for post-pandemic graduate employability and integrating them into universities curricula. Data collected were descriptively analyzed using frequency count and percentage. Findings showed that when universities commit to innovative curriculum delivery, students can easily acquire skills and competencies required to effective security and create jobs in the post-Covid job market effectively recommended that universities should innovate their curricula by integrating post-Covid in-demands skills needed for students' post-Covid job market.
\end{abstract}

\section{Keywords:}

Higher Education Institutions; Curriculum Innovation; Post-Covidskills; Indemand Skills; Curriculum Delivery.

\begin{abstract}
ABSTRAK
Studi ini menjelaskan bahwa dunia kerja pasca-Covid akan menuntut serangkaian keterampilan kerja baru dan institusi pendidikan tinggi perlu merespons dengan mempersiapkan lulusan dengan keterampilan kerja pasca-COVID-19 yang nyata melalui kurikulum yang disampaikan secara inovatif. Melalui tinjauan literatur, penelitian ini mengidentifikasi keterampilan kerja yang dibutuhkan pasca-Covid-19 dan cara-cara untuk mengembangkannya secara inovatif. Studi ini mengadopsi metode survei deskriptif dan meneliti (104) pendapat anggota fakultas (dari 9 universitas negeri) melalui jajak pendapat online tentang keterampilan yang mereka
\end{abstract}


anggap relevan untuk kelayakan kerja lulusan pasca-pandemi dan cara mengintegrasikannya ke dalam kurikulum universitas. Data yang terkumpul dianalisis secara deskriptif dengan menggunakan hitungan frekuensi dan persentase. Temuan menunjukkan bahwa ketika universitas berkomitmen pada penyampaian kurikulum yang inovatif, siswa dapat dengan mudah memperoleh keterampilan dan kompetensi yang dibutuhkan untuk secara efektif mengamankan dan menciptakan lapangan kerja di pasar kerja pascaCovid. Direkomendasikan bahwa universitas harus berinovasi dalam kurikulum mereka dengan mengintegrasikan keterampilan sesuai permintaan pasca-Covid yang dibutuhkan untuk pasar kerja pasca-Covid siswa.

\section{Kata Kunci:}

Institusi Pendidikan Tinggi; Inovasi Kurikulum; Post-Covidskills; Indemand Skills; Penyampaian Kurikulum.

\section{Introduction}

The advent of the Covid-19, which resulted in a global pandemic, is blowing a massive wind of change across every sector known to man. Every sector that wants to remain relevant to the postCovid-19 society needs to begin devising means and strategies of doing so. This is necessary and unavoidable because, more than ever before, the global pandemic has changed the traditional ways of doing things. Every sector, from business to sports, aviation to education, has witnessed a disruption of activities and, in most cases, a total lockdown of their regular and day-to-day activities. There is hardly any sector that has not experienced any form of disruption as a result of the pandemic. As explained by Sutherland, Taylor, and Dermody (2020), there is a need to come to terms that the present world has changed, and people and systems must adapt and change alongside. More worrisome is the fact that Covid-19 has come to stay and must be tolerated for a long time (Kissler, Tedijanto, Goldstein, Grad, \&Lipsitch, 2020).

Cheremond (2020) and Kropp (2020) explained that one of the significant ways the Covid-19 pandemic has impacted the world of work is by changing how people work and accelerating conversations about the future of work. Mudditt (2020) captures it more vividly by saying that the months of the Covid-19 lockdown have significantly changed the professional work environment due to remote working and virtual engagements. He stated that these changes might eventually become permanent. The reality of the impact of the Covid-19 pandemic has forced businesses and organizations to adopt new techniques and smart technologies to respond to the scourge of the pandemic. Even though businesses and organizations were quietly transiting to digital operations before the pandemic, the pandemic created an aggressive momentum for businesses and corporations to reorganize, adapt and leverage new technologies to get things done and to beat the unprecedented loss that came with the pandemic. One of such successful new and smart techniques proved reliable during the pandemic is working remotely and telecommuting. 
Working virtually, which can also be referred to as remote work, has been explained as any work belonging to any institution done or performed outside the confines of the traditional working space or time. It is also a work done largely in spaces other than the traditional settings or spaces of work. Olson, 1983 and Klopotek, 2017 indicated that this type of work is essentially associated with flexibility, adaptability, technology, and modern-day work. Working remotely demands a fresh set of skills differently from traditional or pre-Covid jobs. Al-shathry (2012), in her explanation, pointed out what she considered to be outstanding skills that a remote worker should possess to include technological skills, time management skills, problem-solving skills, decision-making skills, and supervisory skills. Kolpotek (2017) identified that working remotely requires a high level of self-motivation, self-discipline, physical fitness, ability to maintain concentration, and individual control over the pace of work since there is no direct supervision.

In the midst of the pandemic, Guyot \& Sawhill 2020; Shafizadeh et al., 1998; Khalifa \& Davison, 2000 and Rouse \& Smith 2020 indicated that through remote working and telecommuting, many organizations and businesses have been able to maintain social distancing, improve work flexibility, increase productivity, cut office maintenance cost, retain their employees and keep their businesses and organizations running. Some of the findings of Papanikolaou and Schmidt (2020) (in a study carried out to determine the benefits of working remotely during the Covid-19 pandemic) shows that sectors whose work could be remotely done had an advantage of maintaining or even growing their revenues, retaining their employees and improving their stock performance on the stock exchange market. In the same way, workers who could work remotely had fewer chances of being exposed to Covid-19 and greater chances of retaining their jobs or securing new ones. On the other hand, employees who could not work remotely had higher Covid-19 exposure, and the possibility of job declines than workers who could work remotely. It was also found that firms whose work could not be done remotely were the worst hit during the Covid-19 lockdown as they experienced significant declines in revenue growth, stock market performance, and employee retention.

In response to this reality, companies and organizations that have not migrated to the virtual space are rethinking their existing business/operational models and are pursuing aggressive transition and acceleration of their jobs and workforce to the virtual space, while those whose jobs are already on the virtual space are expanding their virtual base in order to maximize the gains and growth that they have so far recorded (Future of Work Accelerated, 2020). In essence, the old order of traditional work is fast being dismantled. The new work order is being institutionalized at a pace faster than any individual could have imagined before the advent of the pandemic, and because of its many uniqueness and benefits (virtual work, remote work, or working from home) is strongly believed to be the post-Covid pandemic future of work.

However, in a more recent identification, Mar (2020), while identifying job skills to survive post-Covid-19, highlighted adaptability and flexibility, technological skills, creativity and innovation, data literacy, critical thinking, digital coding skills, leadership skills, emotional intelligence, and commitment to life-long learning. Furthermore, creativity, persuasion, 
collaboration, adaptability, emotional intelligence, customer service, leadership, communication, problem-solving, video production, affiliate marketing, artificial intelligence analytical reasoning, cloud computing, systems thinking, among many others, were predicted by Nuys (2019); World Economic Forum (2018) and AUDA-NEPAD, (2020) as job skills pertinent to securing employment in 2020 and beyond long before the outbreak of the post-Covid-19 pandemic.

Because of their many benefits, these highlighted skills have been envisaged as necessary and indispensable to the post-Covid-19 pandemic job market. For instance, adaptability and flexibility skills are key since companies and organizations are changing the nature and modes of operations and require employees who can continuously update and refresh their skills to match these rapid changes. Technological skills, data literacy, cloud computing, and digital coding are equally indispensable because companies and organizations envision a future of work where digital transformations can assist them in building a resilient future that is immune to pandemics as being currently witnessed. Also important are soft skills such as emotional intelligence to communicate effectively, network and collaborate with colleagues and show empathy. Leadership capabilities to provide guidance, solve problems, envision growth, and commit to life-long learning.

In essence, the post-Covid-19 in-demand employability skills can be categorized into three, namely: (i) technological expertise and know-how; (ii) emotional and cyber-assisted intelligence; and (iii) Leadership. Without doubt, the post-Covid-19 job realities are presently placing high demands on these skills, and indeed, the post-pandemic will place these skills in high demand as employers would expect that graduates would begin to demonstrate many of these skills in the traditional working space and the virtual space especially now that the nature and scope of work are migrating to the virtual space (Marr, 2020). In fact, employers will begin to look out for these skills as the basis for getting their employees hired during recruitment exercises. Quite frankly, graduates who manifest these skills would be better positioned to secure jobs in the post-pandemic era ahead of graduates who do not demonstrate them. Essentially, the Covid-19 pandemic has disrupted the world of work as it has introduced smart techniques, methods, and ways of getting the job done.

As a matter of fact, the Covid-19 pandemic impact on the world of work bears direct implications on higher education institutions' provision and delivery of academic programs. This is because, as a matter of responsibility, higher education institutions are expected to be at the forefront of creating new technologies and new knowledge that will help society to solve the challenges confronting them (such as the Covid-19 pandemic), which includes preparing and equipping of skilled, educated, independent, and self-directed graduates who would be able to secure or create jobs after graduation. These, amongst many others, are the responsibilities that higher education institutions have delivered consistently to society before the outbreak of the Covid-19 pandemic (Sharma, 2015 and University Leadership and Management, 2012).

However, the covid-19 pandemic looks like a different challenge as it has forced many higher education institutions to a halt in many countries, especially in Africa, where more than 70 percent of these institutions do not have a proven alternative platform to continue with teaching and 
learning (OECD, 2021). It, therefore, appears that higher education institutions that should be beacons are struggling to maintain relevance. As observed by Nicola et al., (2020), in an effort to curtail the spread of the Covid-19 pandemic, tertiary institutions have been suddenly closed down in more than 100 countries, and more than 900 million learners have been affected by the closure of educational institutions. Since this closure was done hurriedly, many higher education institutions closed up in the middle of the semester. This is not without a serious impact on graduating students' career prospects, international students' mobility, scheduled conferences and workshops, and universities fund drive. In some countries, universities have had to refund their student's tuition as a result of growing students' demands and agitation (Sahu, 2020). So, it appears that the institution (higher education institutions) that the society has relied on for years to provide solutions to challenges confronting it is among the worst hit in the wake of the pandemic. Consequently, there is a growing concern and ongoing conversations among stakeholders (governments, businesses, civil society organizations, multinational corporations, etc.) calling to question the relevance of higher education institutions in providing needed solutions to many challenges being thrown up by the Covid-19 pandemic at this critical time.

To stay relevant, higher education institutions in Nigeria need to swiftly respond to multiple challenges that the Covid-19 pandemic has thrown up, especially in the area of bridging students' employability skills gap that the covid-19 pandemic has created, which certainly will become widened post-pandemic. In a report by the African Development Bank (2020), graduates from the West Africa region will not be able to stay competitive or secure competitive jobs post-Covid as a result of lack of job market-aligned skills (in-demand employability skills) and skills mismatch, which would ultimately affect the region's labor productivity growth and industrial competitiveness. These problems have been attributed to the present closure of higher education institutions in the region and the lack of capacity of more than seventy-five percent of these universities to deliver teaching and learning using remote teaching and learning technologies.

For example, in Africa, universities came under sudden closure in response to the pandemic, and more than seventy-seven (77) percent of these institutions terminated every form of curricula delivery. According to OECD (2021), many African universities do not yet have alternative plans of moving to teach and learning online as only twenty-four (24) percent have started developing digital and online learning platforms; this means that more than seventy percent still rely on face-to-face forms of teaching and learning. Gill (2020) explains that a lot has changed in the world of work since the outbreak of the pandemic and lockdown in March 2020. He explained that prior to the pandemic, higher education institutions modeled students' employability skills acquisition around a face-to-face working environment, but the realities of the post-Covid work environment, which emphasizes remote and isolated work environment, require higher education institutions to adopt new methods of teaching and learning that will promote digital and mobile interaction through electronic devices as a way of stimulating new workplace environments for their students. However, in Europe and America, the situation is different as most higher education institutions have digitalized their curricula, and more than eighty (80) percent had set up online teaching and 
learning platforms before the pandemic, an effort that enabled these institutions to respond to online teaching and learning during the pandemic. (OECD, 2021).

However, the successful experiment with new, smart, and cost-effective technologies and techniques with which jobs are remotely done even in the developed economy is one of the reasons why higher education institutions in Nigeria need to deliberately prepare their students with manifest post-Covid-19 in-demand employability skills through innovatively designed and delivered curricula. As institutions saddled with the responsibility of preparing students for the challenges of the future, one of the meaningful ways HEIs in Nigeria would cushion the impacts of the Covid-19 on the employment prospects of their graduates in the post-pandemic job market is through the integration of post-pandemic employability skills into their curricula and its effective teaching and learning to leverage on smart technologies. Therefore, this study is aimed at identifying post-Covid in-demand employability skills and the means of integrating them into universities curricula in Nigeria.

\subsection{Research Questions}

1. What skills do faculty members consider as important for graduates' employability in the post-Covid-19 job market?

2. How best should post Covid-19 in-demand employability skills be integrated into the universities curricula?

\subsection{Theoretical Framework}

\subsubsection{Global Hazards as Trigge1r of Curriculum Innovation}

The continuous change in society is the need for curriculum innovation. In a complementary way, education shapes society, and society shape education. Kolawole (2015) refers to both as Siamese twins that cannot be separated. The very reason that the social experience changes from time to time is why there would never be a once and for all curriculum for all ages (Amino, Bosire, \& Role, 2014). Every generation, based on their needs, challenges, and predicament, will continue to model changes in their curriculum as the need arises. These needs could be the collective aspiration of the people in the areas of governance (such as the quest for democracy, socialism, etc.), science and technology, trade and economics, or international relations. At other times, it could be borne out of the desperate need to survive natural disasters such as famine, drought, or other environmental disasters. It could also be emergencies like wars, health epidemics, and pandemics such as the Covid-19 pandemic the entire world is grappling with.

Global hazards, according to Sinagatulin (2006), play a leading role in enforcing curriculum change. Global hazards bring with them unexpected but sudden realities to curriculum design and delivery. He explained that whenever there is a breakout of war, crime, terrorism, diseases such as HIV/AIDS, natural disasters, and pandemics (such as Covid-19), it is essential for educational institutions to focus educational efforts (such as the curriculum: teaching and learning) on these critical challenges, so there is no wasting of students time in learning what will not be useful to 
them in their present real-life situations. Instead, curriculum content and pedagogy should be refined and updated to reflect the global needs of students. Furthermore, Gardner (1999) explained that in the light of rapid global changes and occurrences, education institutions should be decisive in keeping up with the changes by making relevant and radical adjustments. If this is not done, they run the risk of being replaced by more responsive institutions. Hence, education institutions must be at the forefront of redefining and innovating school curricula (Yeung, Lam, Leung \& Lo; 2012). This is relevant to this study because it explains the need for curriculum innovation in higher education institutions in this present time of global pandemic, which has forced a change in graduate employability skills required for the post-Covid job market.

\section{Methods}

The study adopted the descriptive survey method. Documentary analysis (literature review) was carried out to identify post-Covid-19 in-demand employability skills. A self-constructed research instrument named: Curriculum Innovation for Post-Pandemic University Students InDemand Employability Skills Questionnaire was used to gather data for this study after the validity had been ascertained by experts. Ten (10) faculty members who did not take part in the main study participated in ascertaining the reliability, and the reliability was determined using Cronbach Alpha reliability coefficient of .89. Due to the pandemic, the study adopted convenience sampling; only faculty members who willingly responded to the online survey participated in the study. The instrument was divided into three parts: (a) Name of the institution; (b) important skills for graduate employability in the post-Covid-19 job market, which was divided into three subscales: i technological expertise; ii - emotional and cyber assisted intelligence(s); iii - leadership and (c) means of integrating post-Covid-19 in-demand employability skills into universities curriculum.

The Section $b$ of the instrument had Likert-format scale items with the following scale: $1=$ Not Relevant, 2 = Fairly Relevant, 3 = Relevant and $4=$ Very Relevant. Section c also had Likertformat scale items with the following scale: $1=$ Strongly Disagree, $2=$ Disagree, $3=$ Agree and $4=$ Strongly Agree. The instrument was administered through an online poll, and it determined faculty members' opinions on skills they considered as important for graduate employability in the postCovid-19 job market and means of integrating post-Covid-19 in-demand employability skills into universities curriculum. Data collection lasted for six weeks (01 July 2020 and 10 August 2020), and a total of one hundred and four (104) faculty members' opinions were polled from nine (9) public universities in Nigeria: University of Ibadan; University of Lagos; University of Ilorin; University of Benin; University of Abuja; University of Nigeria; Usman Danfodiyo University; Ekiti State University and Adekunle Ajasin University.

Data collected were descriptively analyzed using simple frequency count, percentage score, mean score (using 2.5 as the criterion norm), and standard deviation. Descriptive Tables were also used to present the data. 


\section{Results and Discussions}

3.1 Skills Considered by Faculty Members as Important for Graduate Employability in the Post Covid-19 Job Market

Table 1. Skills considered by Faculty Members as Important for Graduate Employability in the Post Covid-19 Job Market

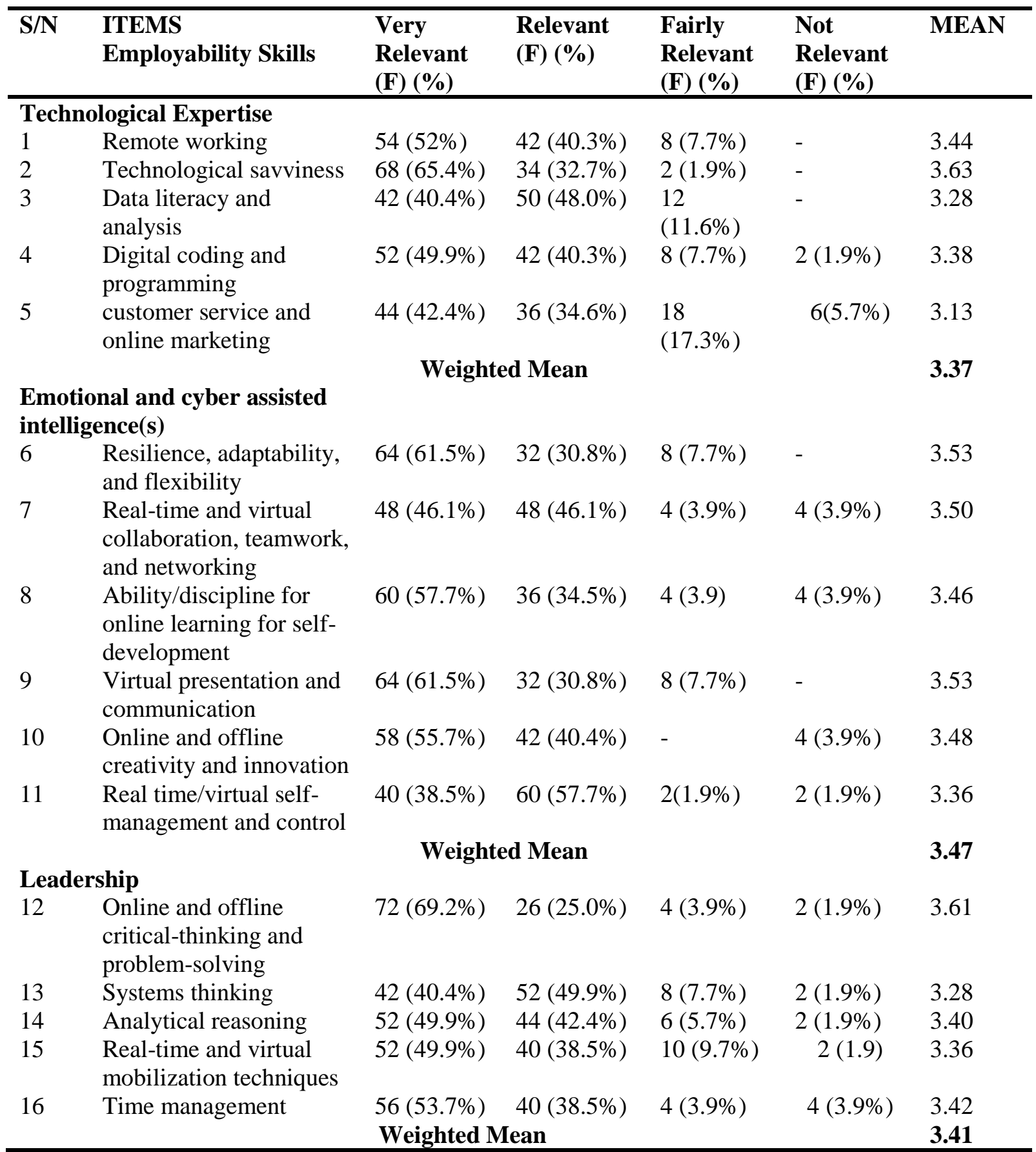


Table 1 presents the skills faculty members considered as important for graduate employability in the post-Covid-19 job market. Findings from the analysis of the data showed that faculty members in Nigerian universities ranked every form of technological expertise very high. The themes included are remote working 92.3\%; technological savviness $98.1 \%$; data literacy and analysis $88.4 \%$; Digital coding and programming $74.9 \%$ and customer service and online marketing $77 \%$ ). The weighted mean is 3.37 , and it is higher than the criterion norm of 2.5 .

Furthermore, faculty members considered emotional/cyber-assisted intelligence(s) as very important for graduate employability in a post-Covid job market by ranking it very high. The themes are online/offline critical thinking and problem-solving 94.2\%; resilience and adaptability 92.3\%; real-time and virtual collaboration 92.2\%; the ability for online learning for selfdevelopment $92.2 \%$; virtual presentation and communication $92.3 \%$; online and offline creativity and innovation $96.1 \%$; and real-time and virtual self-management/control $88.4 \%$ ). The weighted mean is 3.47 , and it is higher than the established criterion norm of 2.5 .

Lastly, faculty members considered leadership as very important for graduate employability in a post-Covid job market by ranking it very high. The themes are online and offline critical-thinking and problem-solving 94.2\%; systems thinking 90.4\%; analytical reasoning 92.4\%; real-time and virtual mobilization techniques $88.4 \%$ and time management $92.2 \%$. The weighted mean is 3.41 , and it is higher than the established criterion norm of 2.5. The results show that faculty members considered technological expertise, emotional and cyber-assisted intelligence, and leadership as critical in-demand skills required for the post-Covid-19 job market.

\subsection{Means of Integrating Post-Covid-19 In-Demand Employability skills into Universities Curricula}

Table 2 presents faculty members' opinions on the means through which post-covid-19 indemand employability skills can be integrated into the universities curriculum. Findings showed that faculty members shared common opinions that when undergraduates are exposed to all forms of remote learning, digital and online learning, higher education institutions are directly creating an atmosphere for students to acquire and develop in-demand employability skills needed to work in a digital workspace (remote) which is becoming isolated due to the covid-19 pandemic. The themes are presented as remote learning $98.1 \%$, digital skills development $100 \%$, discovery of technological potentials $100 \%$, virtual presentation skills $98.1 \%$, virtual up-skilling and re-skilling for life-long learning $88.4 \%$, blended learning 88.4\%, Embedded employability skills assessment framework $94.3 \%$, institutional collaboration with employers $88.4 \%$, institutional emphasis on employability skills acquisition 92.3\%, workplace simulation, and internships, etc. 92.3\%. Digital ethics, virtual communication, virtual presentation, virtual collaboration and networking, coding, and software development, all of which have been identified as post-Covid in-demand employability skills. The weighted mean is 3.50 , and it is higher than the criterion norm of 2.5 . The table shows that faculty members shared the same opinion that post-Covid in-demand skills can be integrated into universities curricula through the methods identified in Table 2. 
Table 2. Means of Integrating Post-Covid-19 In-Demand Employability skills into Universities Curriculum

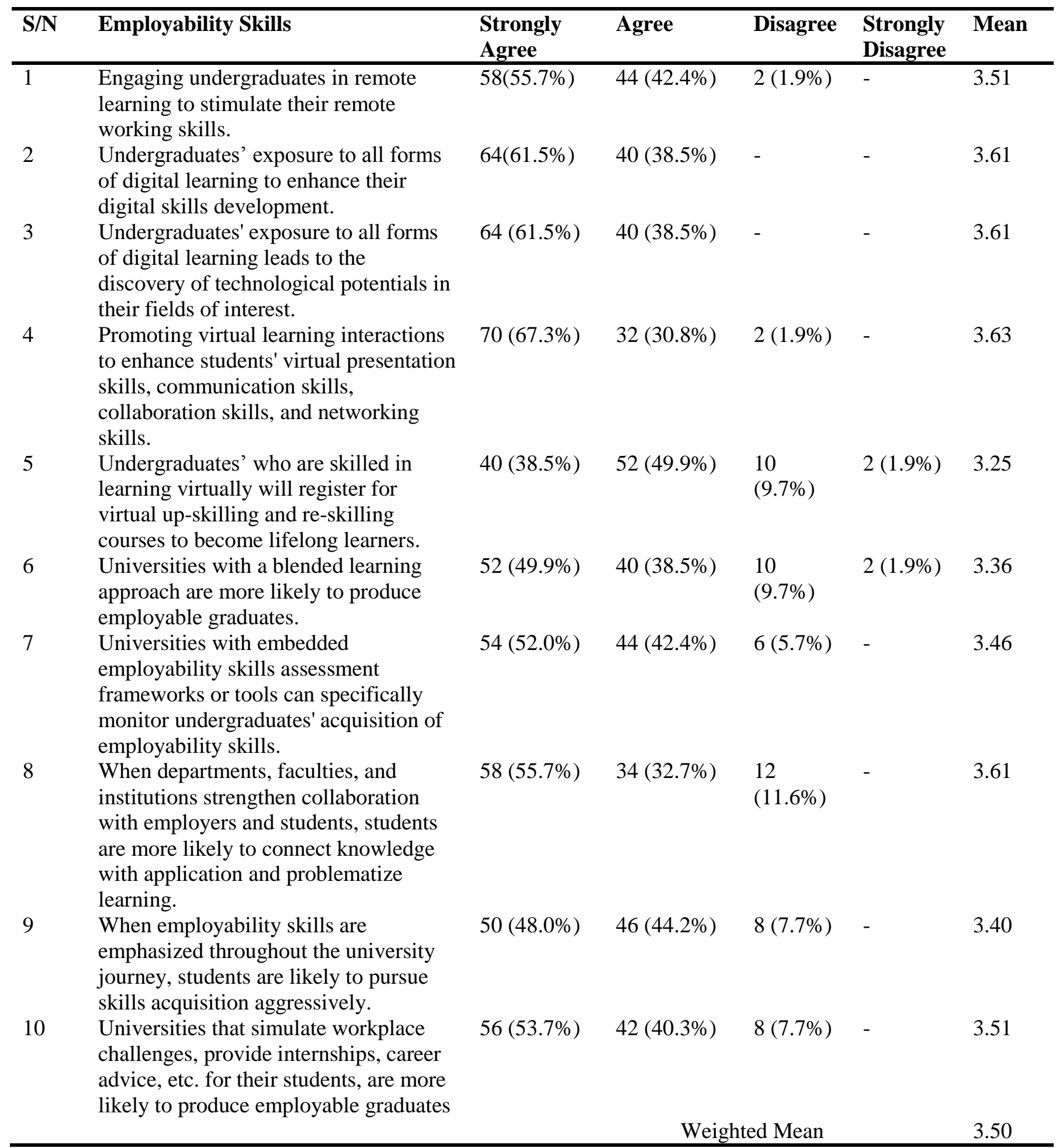


3.3 Skills considered by Faculty Members as Important for Graduate Employability in the Post Covid-19 Job Market

Findings from the study showed that the faculty members shared a similar opinion that the identified post-Covid in-demand skills are important for graduates in order to effectively secure gainful employment in a post-Covid job market. This finding agrees with the submissions of Gill (2020), Mar (2020); WEF (2020); OECD (2020); AUDA-NEPAD (2020), and Nuys (2019) in separate publications that remote working, tech-savviness, digital know-how, problem-solving, critical-thinking, data literacy, adaptability, resilience, flexibility, teamwork, collaboration, lifelong learning, real-life and virtual communication, leadership, self-motivation and control, leadership, time management, systems thinking, customer service, digital marketing among others are indemand skills needed by graduates to survive the post-Covid19 job market.

Though the current curricula of most Nigerian public universities do not directly emphasize the deliberate acquisition and development of these skills, faculty members' realization and acknowledgment that these skills are in demand and are needed by graduates to effectively compete for shrinking jobs in a post-Covid job market are requisite for their readiness to direct instructional delivery methods to stimulate the development of these skills. In addition, faculty members' consideration of these important skills rightly positions them to advise their institutions on the need for curriculum innovation as a means of re-inventing universities curricula to cushion the impacts of Covid-19 on students' job market prospects.

\subsection{Means of Integrating Post-Covid-19 In-Demand Employability Skills into Universities Curricula}

Results from the analysis showed that the faculty members expressed that the means of integrating post-Covid-19 employability skills into universities curricula can better be achieved when students are engaged in all forms of digital and online learning. This is important because when students are engaged in all forms of digital and online learning, they are afforded the opportunity to virtually interact with their facilitators and students, thereby developing virtual cocreation, communication, and tolerant skills.

In the same vein, as students attend classes online, write and submit reports, get feedback and meet important deadlines, their remote working capabilities to attend virtual interviews, meetings, meet deadlines and get feedbacks are actively being enhanced. Digital learning can enable students to identify potential problems that require technological solutions in their field of training, and this can stimulate them to develop applications, software, digital platforms, or any intervention to solve these problems. As succinctly summarized by Gupta (2020), remote learning offer solutions that can revolutionalize the curricula delivery, has the capacity to transform learning, provide hands-on experiences, create exciting teaching-learning interactions that could enhance students' employability skills they will need the moment they enter the world of work. 
Furthermore, Mattis (2018) and Levin and Mudd (2018) recommended that for universities to ensure graduate employability, universities need to integrate career-focused content into their courses and discussions, create work experience opportunities for as many students as possible; engage with business organizations to facilitate synergy between the skills universities teach and the employability skills that business organizations demand; integrate employability-focused contents into their curricula and emphasize employability through the university's vision and mission statements and through campus support systems available to support students of out-of-class activities.

Similarly, Harle (2020) maintained that universities, in an effort to develop students' employability skills, need to enter into an engaging conversation with employees all through the process of innovating their curricula as they have the capacity to help the universities to understand the competencies, attitudes, and skills that companies expect of graduates. Bennett, Richardson, and MacKinnon (2016), while explaining the means of embedding employability skills into university curricula, stressed the importance of creating institutional employability skills assessment frameworks to monitor students employability skills development, build, sustain and collaborate with industry partners to develop students career prospects, contextualize their skills development and create enabling environments for faculty members, professional associations and career advisers seeking to develop employability skills among students. Gupta (2020) submitted that universities that adopt innovative ways of curriculum delivery such as embedded approaches with institutional emphasis and frameworks for employability skills development have the advantage of producing employable graduates.

\section{Conclusion}

Due to the disruptions witnessed in every sector as a result of the Covid-19 pandemic, the study explained that environments of jobs are changing due to the automation of jobs. Higher education institutions need to prepare graduates with manifest post-Covid-19 in-demand employability skills through innovatively designed and delivered curricula, one of the unique ways of responding to the impacts of Covid-19. The study identified post-Covid-19 in-demands employability skills and ways of fostering them through innovatively designed curricula. The opinions of faculty members were canvassed on the skills they considered relevant for postpandemic graduate employability and means of integrating them into universities curricula. Findings show that there are great similarities between faculty members identified post-pandemic graduate employability skills with the employability skills identified in the literature. Findings further showed that when universities promote remote, digital and online learning, students can easily acquire skills and competencies required to effectively secure and create jobs in the postpandemic job market. 


\section{References}

African Development Bank Group, (2020). East Africa Economic Outlook 2020 Coping with the Covid-19 Pandemic. African Development Bank Group Avenue Joseph Anoma01 BP 1387 Abidjan 01Côte d'Ivoire. www.afdb.org.

African Union Development Agency, (2020). Skills that will be necessary to find a job pos COVID19. Retrieved from: https://www.nepad.org/skillsportalforyouth/news/skills-will- be necessary-find-job-post-covid-19.

Al-Shathry, E. A. (2012). Remote Work Skills. International Journal of e-Education, e-Business, e Management and e-Learning, Vol. 2, No. 6.

Amino, C. A., Bosire, J. \& Role, E. (2014). Theoretical Underpinnings of Curriculum Change Developing Economies: Is Complexity Theory the New Wine in Lewins' Old Wineskin? International Journal of Academic Research in Progressive Education and Development. Vol. 3, No. 3. DOI: 10.6007/IJARPED/v3-i3/950.

Bennett, D., Richardson. S. \& MacKinnon, P. (2016). Enacting Strategies for Graduate Employability: How Universities can best Support Students to Develop Generic Skill Part A.Canberra, ACT: Australian Government, Office for Learning and Teaching, Department of Education and Training(http://www.olt.gov.au/project-how-universities- can-best-support students-develop-generic-skills-enacting-strategies-gradua).

Bentley, D. (2018). How Universities can make Graduates Employable with Connections to Industry. Retrieved from: https://theconversation.com/how-universities-can-make graduatesemployable-with-connections-to-industry-91838.

Cheremond, R. J. (2020). 9 Future of Work Trends Post-Covid-19. Retrieved From: https://www.gartner.com/smarterwithgartner/9-future-of-work-trends-post-covid-19/.

Gill, R. (2020). Graduate employability skills through online internships and projects during the COVID-19 pandemic: an Australian example. Journal of Teaching and Learning for Graduate Employability, 11(1), 146-158.

Gardner, H. (1999). The disciplined mind: What all students should understand. New York Simon \& Schuster.

Gupta, R. (2020). Integrating Job-Relevant Skills into Curricula to Maximise Student Outcome Retrieved from: https://www.timeshighereducation.com/hub/coursera/p/integrating-job relevant-skills-curricula-maximise-student-outcomes.

Guyot, K. \& Sawhill, I. V. (2020). Telecommuting will likely continue long after the pandemic. Retrieved on 20 June 2020 from: https://www.brookings.edu/blog/upfront/2020/04/06/telecommuting-will-likely-continue-long-after-the-pandemic/\#cancel.

Harle, J.(2020). Transforming Core Skills in University Curricula. University World New Retrieved from:https://www.universityworldnews.com/post.php?story=202001130818072.

Khalifa, M. \& Davison, R. (2000). Exploring the TelecommutingParadox. Communications of the ACM. Vol. 43, No. 3. Retrieved from: https://dl.acm.org/doi/abs/10.1145/330534.330554.

Kigoto, W. (2020). University World News Africa Edition. Retrieved from: https://www.universityworldnews.com/post.php?story=20200529085010849. 
Kissler, S. M., Tedijanto, C., Goldstein, E., Grad, Y. H., \& Lipsitch, M. (2020). Projecting transmission dynamics of SARS-CoV-2 through the post-pandemic period.Science.https://doi.org/10.1126/science.abb5793.

Klopotek, M. (2017). The Advantages and Disadvantages of Remote Working from to Perspective of Young Employees. Scientific Quarterly: Organization and Management, Vol. 4, No. 40 Retrieved from www.oamquarterly.polsl.pl.

Kolawole, C. O. O. (2015). Curriculum Design Implementation and Innovation. Ibada UniversityPress: University of Ibadan.

Kropp, B. (2020). 9 Trends Impacting the Future of Work. Retrieved from https://www.industryweek.com/covid19/article/21130761/9-trends-impacting-the-future-ofwork.

Levin, J. \& Mudd, C. (2018). From Curriculum to Career: Connecting Curriculum Outcomes to Future Careers. Teaching and Learning in Faculty Focus. Retrieved from: https://www.facultyfocus.com/articles/teaching-and-learning/from-curriculum-to-careerconnecting-curriculum-outcomes-to-future-careers/.

Mar, B. (2020). 8 Job Skills to Succeed in a Post-Coronavirus World. Retrieved from www.forbes.com.

Mattis, G. (2018). The Importance of Graduate Employability for Universities. Retrieved from: https://www.qs.com/the-importance-of-graduate-employability-for-universities/.

Mudditt, J. (2020). How offices will change after coronavirus. BBC Worklife. Retrieved from:https://www.bbc.com/worklife/article/20200514-how-the-post-pandemic-officewill-change.

Nicola, M., Alsafi, Z., Sohrabi, C., Kerwan, A., Al-Jabir, A., Iosifidis, C., Agha, M., \& Agha, R. (2020). The socio-economic implications of the coronavirus pandemic (COVID-19): A review. International journal of surgery (London, England), 78, 185-193. https://doi.org/10.1016/j.ijsu.2020.04.018.

Nuys, A. V. (2019). New LinkedIn Research: Upskill your Employees with the Skills Companies Need Most in 2020.

OECD, (2021). COVID-19 impact on higher education in Africa. Retrieved from: https://oecddevelopment-matters.org/2021/05/19/covid-19-impact-on-higher-education-in-africa/.

Olson, M.H. (1983). Remote office work: changing work patterns in space and time. Communications of the ACM, 26, 3.

Organization for Economic Co-operation and Development, (2020). Skill Measures to Mobilise the Workforce during the COVID-19 Crisis. Retrieved from: https://www.oecd.org/coronavirus/policy-responses/skill-measures-to-mobilise-theworkforce-during-the-covid-19-crisis-afd33a65/.

Rouse, M. \& Smith S. M. (2020). Telecommuting. Retrieved from: https://searchmobilecomputing.techtarget.com/definition/telecommuting.

Sahu P. (2020). Closure of Universities Due to Coronavirus Disease 2019 (COVID-19): Impact on Education and Mental Health of Students and Academic Staff. Cureus, 12(4), e7541. https://doi.org/10.7759/cureus.7541. 
Shafizadeh, K., Niemeier, D., Mokhtarian, P., \& Salomon, I. (1998). The Costs And Benefits Of Telecommuting: An Evaluation Of Macro-scale Literature. UC Berkeley: California Partners for Advanced Transportation Technology. Retrieved from https://escholarship.org/uc/item/1f01c191.

Sharma, R. S. (2015). Role of Universities in Development of Civil Society and Social Transformation, Proceedings of International Academic Conferences 2604181, International Institute of Social and Economic Sciences. Retrieved from: https://ideas.repec.org/p/sek/iacpro/2604181.html.

Sinagatullin, I. M. (2006). The impact of globalization on education. New York: Nova.

Sutherland, D. M., Taylor, G. M., and Dermody T. S. (2020). Coping with COVID: How a Research Team Learned To Stay Engaged in This Time of Physical Distancing. The American Society for Microbiology. https://doi: 10.1128/mBio.00850-20

University Leadership and Management, (2012). The University Context: An Introduction. The Higher Education Context: The role of Universities. Epigeum Ltd. 13 Princes Gardens London SW7 1NA, UK www.epigeum.com.

World Economic Forum (2016). The 10 Skills You Need to Thrive in the Fourth Industrial Revolution. Retrieved from: https:/www.weforum.org/agenda/2016/01/the-10-skillsyou-need-to-thrive-in-the-fourth-industrial-revolution/.

World Economic Forum (2018). The Future of Jobs Report. Centre for the New Economy and Society. Insight Report.

World Economic Forum (2020). Sustainable Development Impact Summit. Retrieved from: https://www.weforum.org/agenda/2020/08/covid-19-jobs-key-skills/.

Yeung, S. S. Y., Lam, J. T. S., Leung, A. W. L. \& Lo, Y. C. (2012). Curriculum Change and Innovation. Hong Kong University Press, Hong Kong. www.hkupress.org. 